\title{
DOCTORS AND ARCHITECTS - DO THESE PROFESSIONS HAVE ANYTHING IN COMMON?
}

DOI: $10.36740 /$ WLek202108138

\author{
Józefa Dąbek', Halina Kulik², Oskar Sierka ${ }^{3}$, Magdalena Szynal ${ }^{4}$, Zbigniew Gąsior ${ }^{1}$ \\ 'DEPARTMENT OF CARDIOLOGY, FACULTY OF HEALTH SCIENCES IN KATOWICE, MEDICAL UNIVERSITY OF SILESIA, KATOWICE, POLAND \\ 2DEPARTMENT OF PROPAEDEUTICS OF NURSING, FACULTY OF HEALTH SCIENCES IN KATOWICE, MEDICAL UNIVERSITY OF SILESIA, KATOWICE, POLAND \\ 3STUDENT RESEARCH GROUP, DEPARTMENT OF CARDIOLOGY, FACULTY OF HEALTH SCIENCES IN KATOWICE, MEDICAL UNIVERSITY OF SILESIA, \\ KATOWICE, POLAND \\ ${ }^{4}$ DOCTORAL STUDIES, FACULTY OF HEALTH SCIENCES IN KATOWICE, MEDICAL UNIVERSITY OF SILESIA, KATOWICE, POLAND
}

\begin{abstract}
Both architecture and medicine have accompanied man for centuries. Both architects and doctors make every effort to ensure that the objects of their interest (buildings and the human body) comply with the Vitruvian principles of ideal construction. Doctors take steps to restore these principles in the event of a disease, and like architects, they try to keep the subject of their activities as Iong as possible. It can be said that this two professions have a common ancestor: the first physician known by name in general history - Imhotep - was not only an outstanding doctor, but also an architect. He designed and built the funerary complex in Saqqara on the basis of a combination of different types of burials from lower and upper Egypt. He also was the author of the prototype of the Edwin Smith Papyrus, discovered in Luxor, a document containing the rational and scientific approach of ancient physicians to diseases for which science dominates over magic. Historians are debating whether it is Imhotep, and not Hippocrates, who should be called the father of medicine. The 21st century forces both doctors and architects to take up newer and newer challenges and change standards. Both of these professions today are based on the service provider-recipient relationship. According to modern technologies, they both work in accordance with the guidelines displayed on the computer screen. Doctors take responsibility for human health and life, while architects - for interpersonal relationships created in the buildings they have designed.
\end{abstract}

KEY WORDS: doctors, professions' combination, architects

Wiad Lek. 2021;74(8):2004-2010

\section{INTRODUCTION}

Both architecture and medicine have accompanied man for centuries. The first buildings included in the history of architecture date back to around 9,000 BCE. These were Neolithic temple buildings in Göbekli Tepe and Nevali Cori on the border of today's Turkey and Syria [1]. If, on the other hand, we look at the first mentions of disease prevention, the members of primitive communities took basic steps to protect against unfavorable natural factors, such as cold or bad weather. They made primitive clothing, built shelters, and began to discover the benefits of hygiene. Among the methods of "treatment" used at that time, one should look for behaviors modeled on animals. This includes, for example, sparing a damaged limb, removing foreign bodies or washing wounds. Egyptian birds - ibises - with a very long neck, use an enema-like procedure: they draw water with their beaks and rinse. On the other hand, elephants, by putting a leg to a cut reed, open a vein and bleed their blood [2]. In the described times, it was the need for recovery and observation that were the best teachers of the healing arts [3].

Despite the activities of architecture and medicine in such different areas of life, both for connected and discon- nected with them people, it is worth considering whether both professions workers do not have common features with each other?

\section{REVIEW AND DISCUSSION}

\section{SIMILAR ASSUMPTIONS UNDERLYING THE TWO PROFESSIONS}

Roman architect Marcus Vitruvius Pollio, who lived in the 1 st century BCE, known commonly as Vitruvius, author of the oldest known treatise entitled "Ten Books on Architecture" (approx. 20-10 r. BCE) defined the basic principles of designing and erecting buildings. He included: strength (firmitas), utility (utilitas) and beauty (venustas) [4]. The human body fits perfectly into the Vitruvian assumptions of the building. It is undoubtedly a beautiful structure in its complex actions and structure. Useful, looking from the perspective of hundreds of human activities possible, as well as permanent. Let the age of the oldest person in the world prove the durability of the human body. Kane Tanaka is 118 years old Japanese born in 1903 when the Wright brothers built the first engine-powered airplane. To imagine what 
progress has been made in both medicine and construction (not only buildings but also machines), from the birth of $\mathrm{K}$. Tanaka, it should be noted that she lived to the time when space trips became possible for every „Smith”.

Both architects and doctors make every effort to ensure that the objects of their interest (buildings and the human body) comply with the Vitruvian principles of ideal construction. Doctors take steps to restore these principles in the event of a disease, and like architects, they try to keep the subject of their activities as long as possible.

These professions are practical and focused on human well-being. It is therefore worth recalling at this point Janusz Dietrych's theory of construction, which is a general methodology for optimizing changing the surrounding reality. There are attempts in the literature to translate its assumptions into diagnostic and therapeutic procedures in medicine [5]. The basis of J. Dietrych's methodology is the dynamic optimization of the utilitarian creative process, and both doctors and architects use this process in their work. For architects it is of course creating a product (house, building, landscape), while for doctors it is the process of treating a sick person. Table I presents the stages of the mentioned process, described in accordance with the methodology of J. Dietrych, and their translation into the work of an architect and a physician [5].

\section{COMMON ANCESTOR: \\ IMHOTEP - DOCTOR, ARCHITECT}

Few people, even among medics, know that the first physician known by name in general history - Imhotep (Fig. 1), was not only an outstanding doctor, but also an architect.

Sometimes called "Leonardo da Vinci of ancient times", "singly", thanks to his incomparable mind, he opened a new era in the history of ancient Egypt [6]. Imhotep was most likely born in the village of Gebelein about 40 kilometers from the ancient city of Thebes, according to the ancient division, in Upper Egypt.

It is not certain whether he belonged to the royal family, but during the reign of the 3rd dynasty pharaoh - Djoser (Necherichet) (2667-2648 BCE) he obtained the highest possible titles available at that time [7]. His full title abounds in the functions he performed at the court of his great pharaoh: Chancellor of the King of Lower Egypt, First after the King of Upper Egypt, Administrator of the Grand Palace, Hereditary nobleman, High Priest of Heliopolis, Builder, Sculptor, Doctor, Maker of Vases of the Lord [8]. The ancients attributed to him the invention of writing. Before Imhotep's achievements are presented, it is worth noting that in ancient Egypt, most architects and builders were anonymous. They built to commemorate the pharaoh or other magnates for eternity - Ad maiorem regis gloriam, paraphrasing the medieval idea of cathedral builders. As noted earlier Imhotep undoubtedly played an important role in the court of the pharaoh Djoser. This is evidenced by the fact that the first mention of Imhotep in the history was found on a statue of Pharaoh Djoser himself discovered in the area of the first pyramid in history, the design and construction of which is attributed to Imhotep (Fig. 2).

As already mentioned, Imhotep with his architectural achievements began a new era in the history of ancient Egyptian architecture. The main change he made was the type of building material from which he carried out the accepted orders. Brick made of mud and reed grass were replaced with stone, the most durable building material known at that time. It should be emphasized at this point that mud brick was still used in the construction of „temporal” buildings. The stone was earmarked for the construction of tombs to ensure a safe life after life, as well as temples and statues [6].

Djoser's pyramid is only part of the huge necropolis in Saqqara. It is a six-story monument. The first of its kind in the world. It was 62 meters high, which in the 27 th century $\mathrm{BCE}$ gave it the status of the highest structure of that period in the world [9]. The pyramid was built in several stages [10-12]. Initially, a mastaba (kind of tomb in the shape of a truncated pyramid) was built. Than whole structure expanded to a four- and then a six-story stepped pyramid. Under the pyramid, a labyrinth of corridors, chambers and galleries with a total length of over $6 \mathrm{~km}$ was built, connected by a central 28 meters deep shaft (Fig. 3).

This space allowed for the king's burial with members of his family and the equipment necessary for the afterlife. Most likely, as a result of the robberies, no mortal remains of Pharaoh Djoser were found, although some scientists claim that Djoser never rested in his tomb $[10,13,14]$. The pyramids did not only function as the body's final resting place. In addition to serving as a tomb, they were built as a monument to the wonderful and fruitful life of the deceased. They were also places of worship where the Egyptians could pray to their God pharaohs. The area around the pyramid (approx. 15 ha) was made up of buildings necessary for both temporal and afterlife. The entire complex was surrounded by a wall almost 11 meters high, of which only fragments have survived to this day. In the original wall there were 13 so-called The "false door" through which the $\mathrm{Ka}$ (the part of the soul remaining on earth, guarding the body of the dead) of Pharaoh could pass between the worlds of the living and the dead. For the „living" who wanted to visit or pray in one of the temples of the necropolis there was a fourteenth door in the south-eastern part of the wall. They were the only entrance road to the entire complex.

Imhotep, in addition to introducing new materials, used his talent to add even greater glory and modernity to his pharaoh's tomb complex. The pillars supporting the main entrance to the tomb were shaped by bunches of reeds and papyrus, which had not only an artistic but also a religious dimension, as well as a symbolic reference to the traditional methods of supporting ceilings in ancient Egypt. In addition, it is worth mentioning that the shape of the columns, as well as their capitals (palm, papyrus, lotus), the presence of various grooved textures, imitations of reed bundles or rows carved in stone, duplicated royal cobras (ureus), symbolizing the power of the pharaoh (Figure 4), marked trends in ancient Egyptian construction for the 


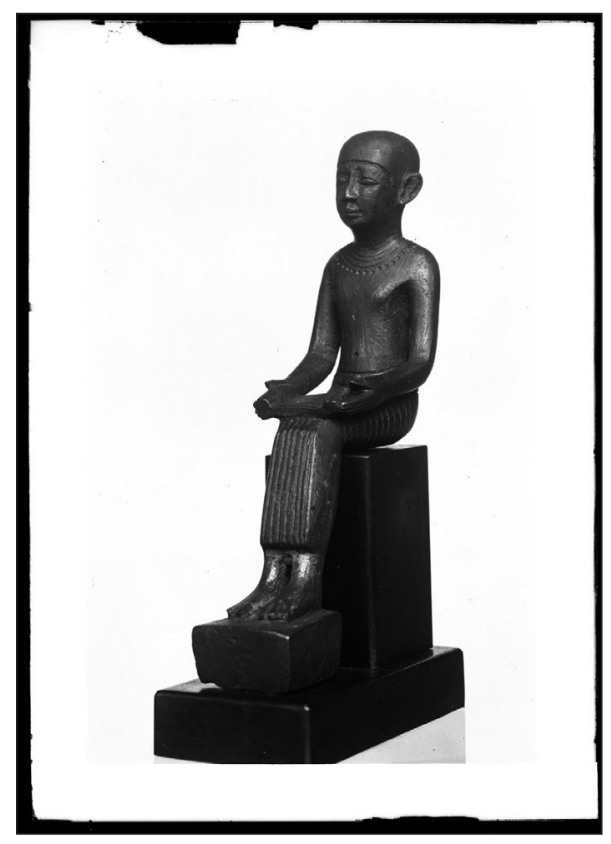

Fig. 1. A figurine of Imhotep.

(Source: https://www.brooklynmuseum.org/opencollection/objects/117029)

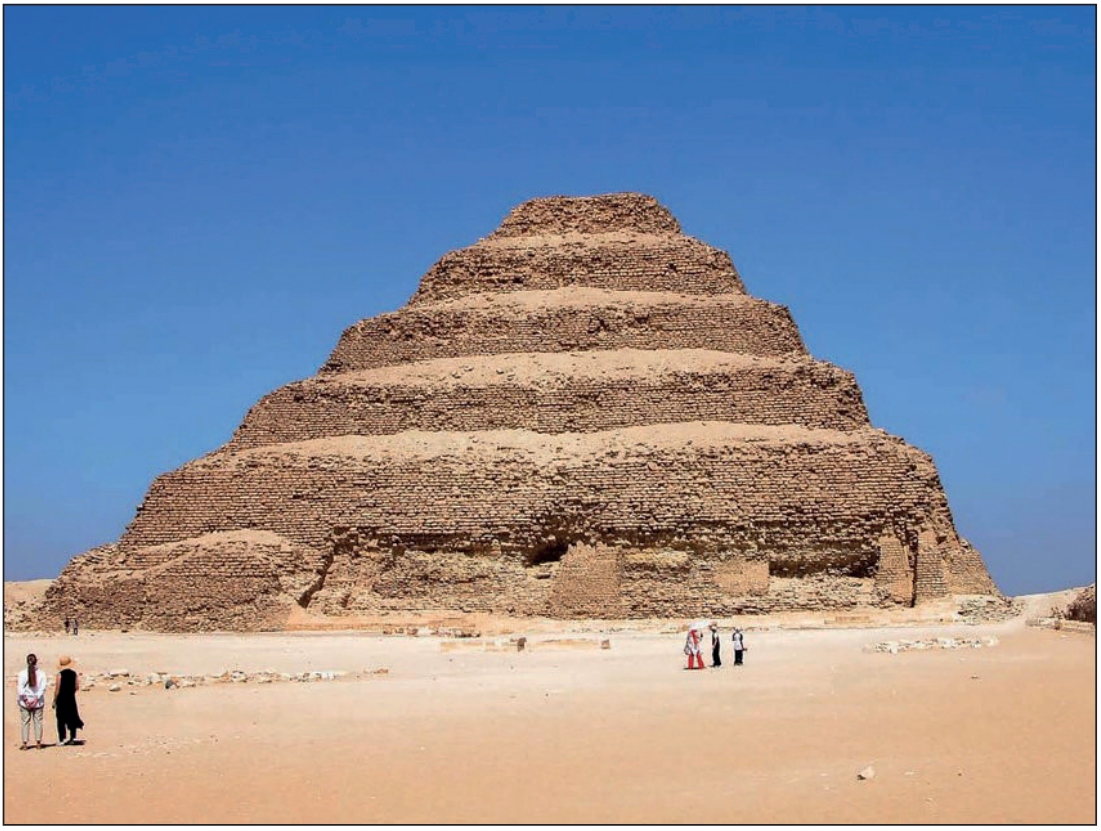

Fig. 2. Djoser's pyramid in Saqqara.

(Source: https: // commons. wikimedia.org/w/index.php? Curid = 66938816.)

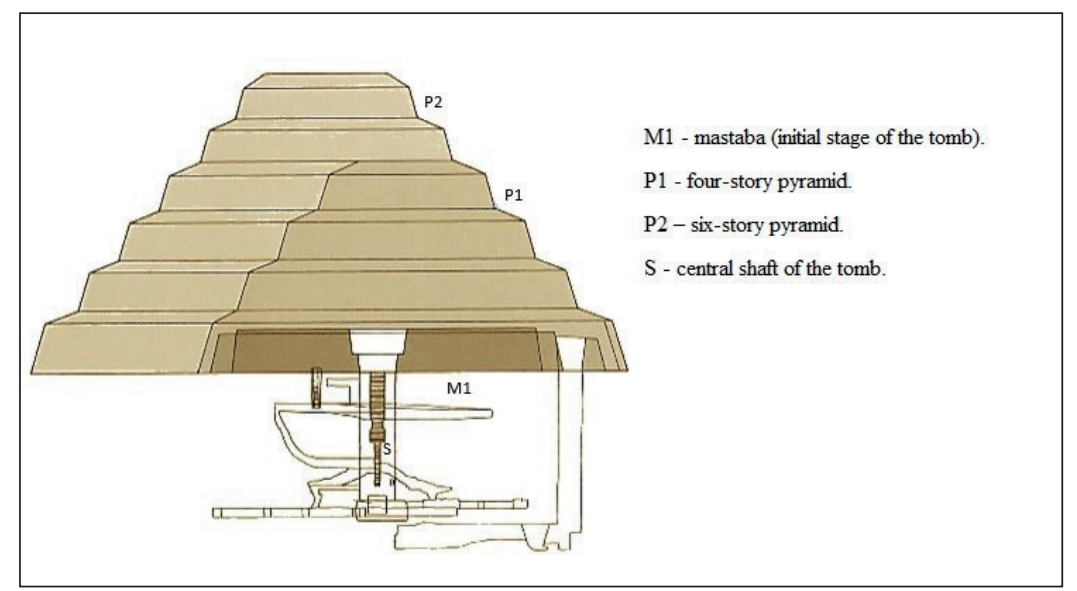

Fig. 3. Stages of Djoser's pyramid construction- diagram.

(Source: based on http://www.narmer.pl/pir/dzeser_pl.htm)

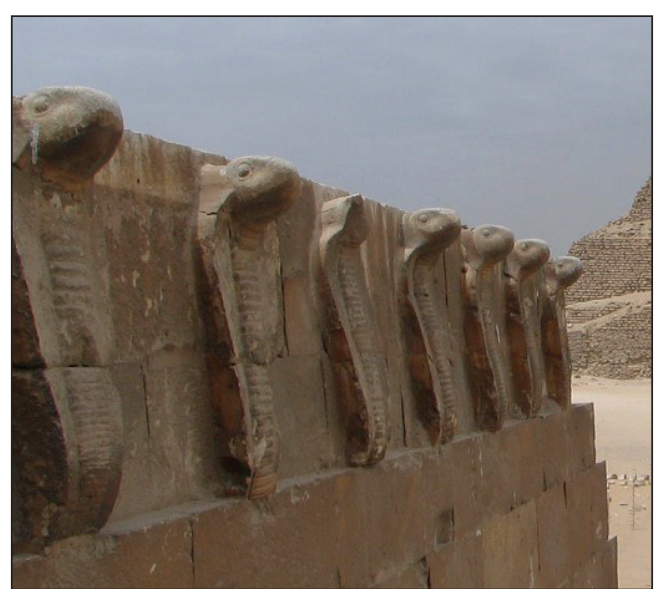

Fig. 4. Ureus adorning the tomb complex in Saqqara. (Source:https://pl.wiktionary.org/wiki/ureusz\#/media/ Plik:Djoser_Pyramid_Cobra_Frieze_detail.jpg)

Table I. The stages of the creation process, described in accordance with the methodology of J. Dietrych, and their translation into the work of an architect and a doctor [5].

\begin{tabular}{ccc}
\hline Stages of creation by J. Dietrych & Architect's work & Doctor's work \\
\hline I- diagnosis of needs & $\begin{array}{c}\text { Recognition of the client's needs regarding } \\
\text { the building }\end{array}$ & Identification of ailments and symptoms \\
\hline II - designing & Building concept & Initial diagnosis of the disease \\
\hline III - constructing & The resulting project of the building & Patient treatment plan \\
\hline IV - production & The resulting building & Patient treatment process \\
\hline V - exploitation & Building exploitation & Further treatment of the sick person and \\
preventing complications
\end{tabular}

next hundreds of years [6].

Imhotep, as already mentioned, was not only an architect and builder, but also a doctor. It is therefore impossible not to mention Imhotep's achievements in the field of medicine. Historians are wondering whether it is Imhotep, and not Hippocrates, who should be called the father of the 
aforementioned science. There is also a possibility that the text of the famous Hippocratic Oath has connections with ancient Egyptian science and texts [15,16]. Researchers suggest that he was the author of the prototype of the Edwin Smith Papyrus, discovered in Luxor in 1892 - a document containing the rational and scientific approach of ancient medics to the topic of diseases in which science dominates over magic (Figure 6) $[17,18]$. It contains descriptions of procedures and 48 injuries arranged from the top of the skull to the lumbar spine [3]. It should be emphasized that the injuries were described in a systematic and unusual, for those times, scientific manner. Each description consists of a title, examination procedure, diagnosis and possible treatment. Additionally, all cases are summarized in one of three possibilities: a positive, neutral prognosis or the statement that „this ailment should not be treated" [19]. Throughout the work, there are 14 cases of incurable diseases, as well as the first descriptions of the sutures of the skull, the meninges, the applied dressings or the relationship between spinal cord injury (e.g. after a combat injury), and multi-organ disorders.

The greatness of the doctor-architect Imhotep is also evidenced by the fact that two thousand years after his death, he was elevated to the rank of God by the ancient Egyptians. During the New Kingdom, scribes considered him their patron. In honor of the great Imhotep, before starting work, they poured a few drops of water from the jugs, which would bring them good luck. Imhotep also patronized craftsmen and doctors. With time, when he became popular throughout Egypt, he was addressed in prayers with matters of everyday life $[8,20]$. Historians believe that Imhotep was associated by the Ancient Greeks with their „medical” deity - Asclepius.

\section{DOCTORS-ARCHITECTS, ENGINEERS, MATHEMATICIANS, ASTRONOMERS ...IN MODERN TIMES}

In the Middle Ages, little attention was paid to keeping the names of architects, and most of the buildings were built for cult purposes. The authors did not find any physician linking medicine with construction from this period.

During the Renaissance, medicine and architecture experienced a revival. The leading representative of that time was Leonardo da Vinci. He was involved in artistic activities, flora and fauna, hydrology, hydraulics, as well as decoration, costume design and philosophy. He made sketches and plans for war machines, defensive walls and other works known to this day. Da Vinci was also interested in the anatomy of the human body. During his anatomical studies, together with Professor Marcantonio della Torre, he performed illegal autopsies, thanks to which he learned about the connections between the skeletal system, muscles and tendons. He is also credited with the first accurate depiction of the fetus in the womb. Interestingly, he gained knowledge on this subject by examining a pregnant cow. Leonardo also made casts of the human brain and ventricles, studied the effects of rib and diaphragm movement, and aspects related to circulation. He concluded that arteriosclerosis causes premature death, and that it could be prevented by moderate exercise and better diet. He is assigned the title of the first medical physicist on the basis of his detailed understanding of the human body, illustrated by drawings and sketches [21,22].

Girolamo Cardano, whose greatest contribution in the field of medicine, was the first description of typhus also deserves attention as a representative of the Renaissance. He was also a gifted mathematician and mechanic, he published a methodology for solving third and fourth degree equations and designed the universal joint, which is still used today in machines with drive transferred in various axes [23].

Nicolaus Copernicus is known for his achievements in astronomy, but for 40 years he also practiced medicine. In 1501, Copernicus began three-year medical studies in Padua, obtaining the right to practice. After returning to Poland, he became a doctor of the Warmia Chapter. He also conducted correspondence consultations on more complicated clinical cases with Jan Benedykt Solfa - the personal physician of King Sigismund the Old. He also showed knowledge in the field of construction. During the epidemic on the coast in 1519, according to his recommendations, an innovative water supply was built, and the population of many villages in Warmia and Pomerania was provided with clean water [24].

In the Baroque period, Claude Perrault should be distinguished among physicians - architects. In 1641, he obtained a doctorate in medical sciences at the University of Paris, and later became one of the first members of the French Academy of Sciences, but it was his achievements in the field of architecture that brought him the greatest fame. In 1673, he translated the treatise Ten books on Architecture by Vitruvius, mentioned at the beginning of the article, into French, and later himself wrote a treatise on the five classical architectural orders. Together with Louis le Vau and Charles le Brun, he was commissioned by Louis XIV to design the eastern façade of the Louvre. He also devised a method of bonding the stones without mortar, making them an inseparable and durable mass, which was discovered during the demolition of the unfinished triumphal arch on Rue St-Antoine in Paris. He also designed the Paris Observatory, Colbert's Palace in Sceaux, the triumphal arch at Place du Trône (now Place de la Nation) and the Tethys grotto in Versailles $[25,26]$.

William Thornton is another example of a physician who turned to the architecture. He started in a medical internship at the age of 16 , and then studied at the University of Edinburgh for three years. In 1784 he began doctoral studies in medical science at the University of Aberdeen. Although he initially wanted to work as a doctor, in 1788 he went to America, where he abandoned medicine and became interested in architecture. Having no education in this field, he made the project of Capitol Hill in Washington. He also designed the building of the University of Virginia, and together with his fellow inventor, John Fitch, developed the structure of a paddle-wheel steamer [27].

Nowadays, in the literature appeared the term "docitect”, which is a combination of two words: doctor + architect. 
An example of such person is Dr. Diana Andreson, who, being both an architect and a doctor, worked on hospital projects in the United States, Canada and Australia, planning geriatrics and intensive care units [28]. When writing about doctors-architects, it is impossible not to mention our compatriots. Among them, one should mention Dr. Józef Brudziński, who designed such buildings as: Charles and Mary for Children, opened in 1913 in Warsaw, or the Hospital of Anna Maria in Łódź. In order to learn about the use of the latest architectural solutions and devices in hospital buildings, he visited children's clinics all over Europe [29]. Another one is Dr. Kazimierz Bednarek, who was one of the initiators of the builders of the new hospital building at Poznańska Street in Inowrocław [30]. The 110-year-old Hospital in Tomaszów Lubelski owes its intensive expansion to doctor Janusz Peter, who in the years 1927-1963 was the director of the facility, combining many passions at work: construction, economy and medicine [31].

\section{THE PRESENT AND THE FUTURE OF BOTH PROFESSIONS}

The 21st century forces both doctors and architects to take up newer and newer challenges and change standards. The changes taking place in the development of research and technology, as well as access to knowledge, are changing the approach of doctors to patients and vice versa.

Nowadays, between above-mentioned fields cooperation is needed. Doctors can be consultants during hospital design, contributing to the creation of work-friendly facilities. There is also evidence of a correlation between properly designed patient environment and treatment efficacy. The factors positively influencing health include: reducing the noiselevel, adapted lighting, single-person rooms, adequate ventilation, access to daylight and to the "green" environment [32]. Doctors can also act as public health experts in increasing the accessibility of recreational areas and sidewalks, planting vegetation to counteract the effects of air pollution, and the logical distribution of health facilities throughout the city for residents to reach them quickly [33].

Since the spread of private medical practices and the increased access to once-secret medical knowledge, the patrimonial model of patient care, in which the patient obeyed to doctor's words and recommendations, without any protest, as subjected to his ruler, has disappeared. Patient care becomes more of a service provider-customer relationship. The patient as a client (service recipient) comes to the doctor (service provider) and expects the best quality advice and assistance. The form for which he pays is known to everyone: interview, physical examination, issuing recommendations. Contrary to the patrimonial relationship, however, the patient has the right to express an opinion on the service he has received and has the option of not following medical recommendations, which is not advisable, but possible. It is more than possible that if a patient is dissatisfied with the service received, and has not expressed an opinion about it and the doctor in the office, he will do so on one of the generally available online doctor's evaluation portals.
The service provider - service recipient relationship has been practiced by architects for many years. The client reports a need for a plan or performance of a commissioned work and also expects to ensure the highest standard, but taking into account his own opinion.

The aforementioned theory of J. Dietrych can also combine both professions at this point by applying the scheme, which is the Process of Satisfying Needs. At the beginning of each creation process (building / patient treatment) there is an operator (architect / doctor) who creates the project and its construction assumptions. On its basis, operator leads to the creation of a structure, then its manufacture and putting into service [34-36].

Despite how simple both forms of cooperation seem to be, it should be remembered as a client / patient that architecture and medicine are sciences and arts, and in both and out of context, information about the health or whim of the location of the rooms in a new house does not allow for the creation of a full picture and stability, in the case of architecture - a future building, and in the case of medicine - a disease, and the complex process of its treatment. On the other hand, the service provider (doctor / architect) must be able to convince the client that his recommendations and decisions are correct, even if they are not entirely consistent with the client's opinion.

Especially during the prevailing pandemic, but also beyond its duration, the number of physicians working with information and communication technology systems increased significantly. It is more and more common to see the doctor bending over, in a non-ergonomic position in front of the monitor, writing out the necessary columns, selecting the appropriate boxes and „examining” the application screen, not the facial expression or the way the patient moves.

If we look at the work of architects, we will notice a similar dynamics of change as that observed in the work of doctors. An increasing number of them use the virtual world for their work. A few decades ago, young architects spent their time in their studios, standing over drawing tables, talking to each other. With the introduction of computers to the widespread use of computers, the situation has changed dramatically. According to Bruce Snider's description, nowadays architects, like doctors, sit bent over monitors, with headphones on, as if cut off from the real world and remaining for long hours in the virtual world.

The computer routine begins to touch the representatives of both professions. Doctors follow the commands displayed on the monitors, not the intricacies of the patient's medical history. They are forced to translate their touch from the patient to the computer keyboard so as not to harm them and themselves. Especially young doctors often prefer the strings of numbers "spited out" from the labolatories machines over their own intuition. Documentation is gradually replacing communication with both the patient and colleagues. There are situations when a patient's disease is underestimated because its results do not indicate it. It would seem that the next generations of doctors are losing faith in the fact that combining their own knowledge with 
conversation and thorough examination is better than the best computer. And it should be remembered that touch not only allows you to "examine” changes, but also focuses the examiner's attention on a given region of the patient's body. Moreover, it ensures a slow but important building of the doctor-patient relationship. Touch is also a gesture of connection and hope, and often a means of relieving the patient's pain, more powerful than many drugs.

Mentioned above Bruce Snider comes to a sad reflection in his story about young architects. He states that young architects, like young doctors, translate their touch into mouse clicks, instead of pencil strokes on paper. In line with his words, drawing by architects, the so-called „old-fashioned" is the connection between the brain and the paper with the help of the hand. However, many young architects „do not waste time” to perfect this art $[37,38]$.

\section{WHERE ELSE LOOK FOR SIMILARITIES BETWEEN DOCTORS AND ARCHITECTS?}

In both discussed professions, the role of imagination and intuition is very important. When designing a building, an architect must demonstrate skills that allow him to locate his idea in space, combining individual elements of the structure into one piece. The doctor, on the other hand, has to have the human anatomy at one's fingertip and be able to visualize the location of all organs in the human body, as well as their interaction with each other. Both of these professions sometimes have to trust their intuition and design the building or treatment of a sick person in an unconventional way in order to achieve the intended, positive effect, especially in a situation where traditional schemes fail.

The knowledge that both doctors and architects are guided by should be based on facts. Doctors should treat their patients following the latest medical recommendations, while architects should design buildings according to the most recent construction law standards. Both professions must adhere to certain rules and standards in order not to lead to a situation that will make the building designed by the architect unstable and collapse, and the patient led by a doctor will be unstable and may die.

In both professions there are many times when the client / patient is the so-called „Difficult client / patient”. A man who is unhappy, denying everything, annoying or aggressive. The necessary features, both for an architect and a doctor in the case of these people, are, on the one hand, patience and, on the other hand, the ability to set boundaries that those clients cannot exceed. There is also the issue of the work ethic of both doctors and architects. Despite the difficult relationship with the client / patient, they should always be honest with their recipient.

Doctors know the injustice of the disease and know that it can affect anyone, regardless of age, gender, education, or position in society. Generalizing and, as it were, leaving aside all the complexities of doctors' work, their primary task is to relieve pain, delay death and promote a healthy and joyful life. By helping to recover health in the treatment process, or preventive measures, they affect not only the life of the patient, but all those who will come into contact with him in the future. Good health, both preserved and restored, allows the patient to form relationships with family, friends or complete strangers. It also prevents loneliness, exclusion and often deteriorating health. Building relationships gives people the opportunity to influence the lives of others, and others - their lives. The ultimate goal of physicians' efforts, therefore, goes far beyond restoring the patient to his health.

An architects, like a doctors, only in theory works exclusively for their clients. It is worth noting that when designing or building a house, even a single-family house, the decisions made by the architect will not only affect the lives of those living in it, but also those around them. They will affect the interpersonal relationships that arise when the construction of a given facility is completed. Over the years, centuries-old buildings often affect the landscape of a given place, as well as access to resources and air quality. A good architect understands that when designing for people sitting on the other side of the desk, or nowadays a webcam, he must also take into account the welfare of others. Ultimately, the goal of an architect's work also goes beyond creating a design and supervising its execution.

\section{CONCLUSIONS}

Despite allegedly such distant fields of interest as medicine and architecture, representatives of both professions can learn a lot from each other. Both doctors and architects, despite the different social roles and professional tasks, should bear in mind the words of the Argentine architect Rodolfo Livingston: „The attitude of an architect towards a client's request (...) should be analogous to that of a good specialist doctor who never limits his remarks to one organ, which the patient complains about, but examines it in the context of the whole ", and the fact that many features common to both professions can be found [39].

\section{REFERENCES}

1. Schmidt K. Göbekli Tepe - the Stone Age Sanctuaries. New results of ongoing excavations with a special focus on sculptures and high reliefs. Documenta Praehistorica. 2010;37:239-256.

2. Szumowski W. Historia medycyny filozoficznie ujęta. Warszawa: Wydawnictwo Marek Derewiecki, 1994.

3. Seyda B. Dzieje medycyny w zarysie. Kraków: Państwowy Zakład Wydawnictw Lekarskich, 1973.

4. Witruwiusz. 0 architekturze ksiąg dziesięć. Warszawa: Prószyński i S-ka, 1999.

5. KucharzEJ,KotulskaA,ZmysłowskiA.Zastosowaniemetodologii Dietrycha w analizie lekarskiego postępowania diagnostyczno-terapeutycznego. Wiad Lek. 2006;59:293-294.

6. Zinkow L. Imhotep i pawie pióra. Kraków: Księgarnia Akademicka, 2010.

7. Fletcher J. The Story of Egypt. Hachette UK, 2015.

8. Tatereka FF. Najwybitniejsi władcy Egiptu. Pomocnik historyczny, 2018.

9. Bonnet H. Lexikon der ägyptischen Religionsgeschichte. Hamburg: Nikol, 2005, pp. 322-324. 
10. Spencer A. Early Egypt: The Rise of Civilization in the Nile Valley. Londyn: British Museum Press, 1993, pp. 98-110.

11. Lehner M. The Complete Pyramids. New York:Thames and Hudson, 1997, pp. 80-93.

12. Hart G. Pharaohs, and Pyramids, A Guide Through Old Kingdom Egypt. Londyn: The Herbert Press, 1991, pp. 57-68.

13. Parry D. Engineering the Pyramids. Phoenix: Sutton Publishing Limited; 2004, 14.

14. Verner M. The Pyramids. New York: Grove Press, 1998, pp. 105-139.

15. Kucharz EJ. Przysięga Hipokratesa. Komentarz i nowy przekład na język polski. Pol Arch Med Wewn. 2006 126;5(11):1099-1107.

16. Pickett AC. The oath of Imhotep. J Natl Med Assoc 1992;84(7):636-637.

17. Musso C. Imhotep: The Dean among the Ancient Egyptian Physicians. Humane Medicine 2005.

18. Allen J. The Art of Medicine in Ancient Egypt. Yale University Press, 2005:12.

19. Wilkins R.H. R. Neurosurgical Classic XVII: Edwin Smith Surgical Papyrus. „Journal of Neurosurgery”. Charlottesville, Virginia: The American Association of Neurosurgeons, 1964, pp. 240-244.

20. Praca zbiorowa. Historia powszechna. Starożytny Egipt. Grecja i świat helleński. vol. 3. Mediasat Poland sp. z 0.0., 2007, p. 101.

21. Heydenreich L. Leonardo da Vinci | Biography, Art \& Facts | Britannica. 2020, Encyclopædia Britannica. Chicago, Illinois: Encyclopædia Britannica, Inc. [Access: 1.06.2021].

22. Kron T, Krishnan P. Leonardo DaVinci's contributions to medical physics and biomedical engineering: celebrating the life of a 'Polymath'. Australas Phys Eng Sci Med 2019;42:403-405.

23. Britannica, The Editors of Encyclopaedia. "Girolamo Cardano". Encyclopedia Britannica, Invalid Date, https://www.britannica.com/ biography/Girolamo-Cardano. [Access: 1.06.2021].

24. Rutkowski B. Mikołaj Kopernik - z zawodu lekarz, z zamiłowania astronom. Gazeta AMG 2017;27(1):42-45.

25. Introduction by Alberto Pérez-Gómez to Indra Kagis McEwen's translation of Perrault's Ordonnance for the five kinds of columns after the method of the Ancients. Santa Monica, CA: Getty Center for the History of Art and the Humanities, 1993.

26. Dulewicz A. Słownik sztuki francuskiej. Warszawa:Wiedza Powszechna, 1986, p. 323. ISBN 83-214-0048-5.

27. William Thornton (1761-1828) Physician Turned Architect. JAMA. 1968; 206(1): 126.

28. https://www.dochitect.com/dochitect-bio/ [Access: 2.06.2021].

29. Szenajch W. Szpital im. Karola i Marii dla Dzieci. Budowa, organizacja, działalność. Pierwsze dziesięciolecie szpitala 1913-1923. Drukarnia Krajowa w Warszawie, Warszawa 1926, p. 1.

30. Napierkowska R. Lekarz i budowniczy szpitala. https://expressbydgoski. pl/lekarz-i-budowniczy-szpitala/ar/10973961. [Access: 6.06.2021].

31. Augustowska A. Szpital w Tomaszowie ma 100 lat. Medicus. 2011:12.
32. Martin D, Nettleton S, Buse C et al. Architecture and health care: a place for sociology. Sociology of Health and IIIness. 2015;37(7):1007-1022. doi: 10.1111/1467-9566.12284

33. GanskeIA.Different Angle:Physician and Architect. In:Urman R, Ehrenfeld $\mathrm{J}$ (eds). Physicians'Pathways to Non-Traditional Careers and Leadership Opportunities. Springer Science+Business Media; 2012, pp. 263-271.

34. Zmysłowski A. Kryzys osobowości - Zarzewie buntu - Potrzeba reform. In: Osika G (ed.). Bunt i reforma. Kraków: Homini, 2011, pp. 341-369

35. Zmysłowski A. Metodologia profesora Jana Dietrycha w ujęciu ontologicznym - uniwersalne narzędzie zarządzenia. In: Systemy wspomagania. Warszawa, 2006, pp. 121-122.

36. Zmysłowski A. Ontologiczne uwarunkowania nauki. In: Rąb J et al. (eds.). Podmiotowość nauki. Zabrze, 2002, pp. 58-68.

37. Loxterkamp D, Snider B. What doctors have in common with architects part 2: The common good. BMJ 2015:350.

38. Loxterkamp D, Snider B. What doctors have in common with architects -part 1: A manual art. BMJ 2015:350.

39. Livingston R. Cirugía de casas. NOBUKO 1992.

\section{ORCID and contributionship:}

Józefa Dabek: 0000-0002-8257-6614 ${ }^{A-B, D-F}$

Halina Kulik: 0000-0002-1092-814X A,B,D

Oskar Sierka: 0000-0001-8667-6463 B,D

Magdalena Szynal: 0000-0001-8202-6658 ${ }^{B, D}$

Zbigniew Gasior: 0000-0003-3616-8932 F

\section{Conflict of interest:}

The Authors declare no conflict of interest.

\section{CORRESPONDING AUTHOR} Józefa Dąbek

Department of Cardiology, Faculty of Health Sciences in Katowice, Medical University of Silesia

ul. Ziołowa 47, 40-635, Katowice, Poland

tel. +48323598530

e-mail:jdabek@sum.edu.pl

Received: 05.10.2021

Accepted: 30.07 .2021

A - Work concept and design, B - Data collection and analysis, C - Responsibility for statistical analysis, D-Writing the article, $\mathbf{E}$-Critical review, $\mathbf{F}$ - Final approval of the article 